\title{
KARST IN SILICEOUS ROCKS KARST LANDFORMS AND CAVES IN THE AUYÁN-TEPUI MASSIF (EST. BOLIVAR, VENEZUELA)
}

\author{
Leonardo Piccini *
}

\begin{abstract}
During the expedition "Tepuy 93", six caves were explored in the precambrian quartzites, of Roraima Group, in the Auyán-tepui massif. One of this caves reaches the depth of $370 \mathrm{~m}$ and a development of almost 3 $\mathrm{km}$; it's name is "Sima Auyán-tepui Noroeste" and it is currently the deepest cave in the world discovered in siliceous rocks.

The geological and morphological study of this cave has underlined again the importance of deep solutional weathering, along the network of fractures, for the formation of caves in siliceous rocks.

The different formation stages of the big superficial shafts called "simas" were observed in some vertical collapse caves explored during the expedition, while galleries with phreatic forms were observed in the deep network of caves. All these deep forms involve karst processes of solution at least in the initial stage.
\end{abstract}

RIASSUNTO (Il carsismo nelle rocce silicee-Forme carsiche e grotte nel Massiccio Auyan-Tepuy (Est. Bolivar, Venezuela)

Durante la spedizione "Tepuy 93", organizzata dalla Società Speleologica Italiana e dalla Sociedad Venezolana de Espeleologia, sono state esplorate sei nuove grandi grotte sviluppate nelle quarziti precambriane del Gruppo Roraima che formano il massiccio dell'Auyàn-tepui. Una di queste raggiunge la notevole profondità di $370 \mathrm{~m}$ con uno sviluppo spaziale di quasi $3 \mathrm{~km}$; questo sistema, denominato "Sima Auyán-tepui Noroeste", è attualmente la più profonda grotta del mondo esplorata in rocce a composizione prevalentemente silicea.

Gli studi geologici e morfologici compiuti durante la spedizione hanno sottolineato nuovamente l'importanza dei processi di dissoluzione lungo il reticolo delle fratture principali per la formazione delle grotte all'interno di rocce a composizione silicea.

L'esplorazione di diverse cavità ad andamento verticale, chiamate localmente "simas", ha permesso di ricostruire i diversi stadi di formazione di queste impressionanti voragini a cielo aperto, profonde fino a $300 \mathrm{~m}$ ed oltre. Oltre ai grandi pozzi superficiali sono stati esplorati reticoli di gallerie con morfologie riconducibili ad una circolazione in condizioni freatiche. L'origine di tutte queste morfologie ipogee richiede necessariamente, almeno nelle fasi iniziali del loro sviluppo, l'azione di processi dissolutivi propriamente carsici.

\section{INTRODUCTION}

In recent years, superficial and deep karst landforms have been described by many authors in the Precambrian quartzitic massifs of Roraima Group, in the Gran Sabana, in the south-eastern Venezuela (Urbani et al. 1977; Galán, 1988; Briceño \& Scubert, 1990, with bibl.).

In spite of the siliceous lithology of the rocks forming the table-mountain of this region, the landscape of the plateaus shows typical karst landforms like karren-type forms, dolines, sinkholes, stone-forests, caves and impressive shafts called simas.

The karstic character of the landscape is underlined by the fact that the drainage of rain water is mainly through underground networks, with spectacular resurgences along

\footnotetext{
* Società Speleologica Italiana, c/o Dip. di Scienze della Terra, Via La Pira 4, I-50121 FIRENZE, Italy.
} 
the high walls that bound the table-mountain.

The development of karst landforms in very poorly soluble rocks is possible only under rather particular environmental conditions. In this case the long time of weathering, probably longer than $100 \mathrm{Ma}$, is the main factor which has allowed the karstification of quartzite.

To increase the knowledge of this exceptional morphologies, in the dry season of 1993, an expedition, called "Tepuy '93", was organized by the Società Speleologica Italiana and-Associazione "La Venta" with the support of Sociedad Espeleologica Venezuelana. The aim of the expedition was the exploration of new subterranean systems in the Auyàn-tepui. During the expedition, was discovered and explored the "Sima

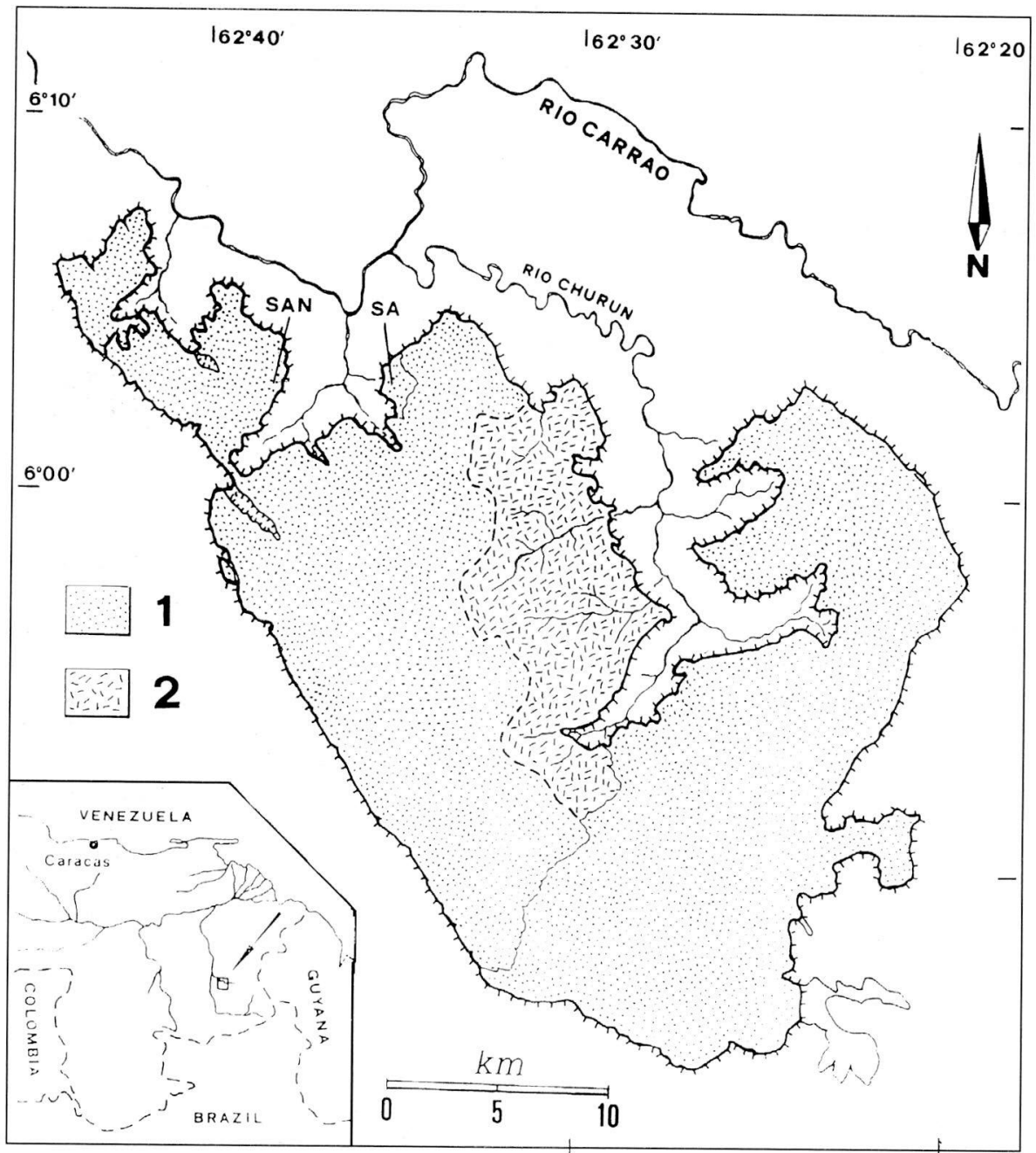

Fig. 1 - Location map of the Auyàn-tepui and the investigated areas: SAN = Sima Auyàn-tepui Noroeste, SA = Sima Aonda. 1) Siliceous arenites (Matauí Formation), 2) Approximative outcropping of diabase. 
Auyán-tepui Noroeste" (SAN) the deepest and largest cave of the world in siliceous rocks (C.G.E.B., 1994, Bernabei et al., 1993).

The explorations were concentrated in three small areas, selected during a previous recognition by helicopter. The three areas are located in the north-western side of the Auyàn-tepui. Two of them were never explored, the third was the platform were the Sima Aonda, the largest sima of Venezuela, opens together with several big shafts already explored by the Sociedad Venezolana de Espeleologia (Galán, 1986).

\section{GEOGRAPHIC OVERVIEW}

The Gran Sabana is a wide geo-morphological province of the Guayana shield; the region is crossed by several affluents of Rio Caroní, flowing into the Orinoco River.

The main massifs of the Gran Sabana have the shape of a large table mountain, locally named "tepuy" the Pemón word meaning mountain. The tepuy are delimited by vertical to overhanging walls, often 400 to more than $1000 \mathrm{~m}$ high. Many of these tepuis are not yet explored; since the only way to reach them is by helicopter.

The Auyán-tepui (Fig. 1) is located from $5^{\circ} 45^{\prime}$ to $6^{\circ} 05^{\prime}$ of latitude $\mathrm{N}$ and from $62^{\circ}$ $20^{\prime}$ to $62^{\circ} 45^{\prime}$ of longitude W. It represents one of the widest tabular-shape mountain of the Gran Sabana; the "Devil's Mountain" (auyán = devil) has an area of about $700 \mathrm{~km}^{2}$ and a maximum elevation of $2800 \mathrm{~m}$; together with Pico Neblina $(3045 \mathrm{~m})$ in Brasil, and Roraima M. (2810 m), also in the Gran Sabana, it is one of the highest non-andine mountains of the South America.

This massif became famous with the discovery of the Angel's Fall, the highest waterfall in the world, which jumps from the rim of the plateau with a drop of $972 \mathrm{~m}$.

\section{GEOLOGY}

The Gran Sabana is part of the Guayana Shield, the oldest portion of the South American craton. The igneous and ultra-metamorphic rocks outcropping in the northern side of the shield (Imataca-Bolivar Province, after González de Juana et al, 1980) have an age of $3.5 \mathrm{Ga}$.

The Auyán-tepui belongs to the Roraima-Canaima Province, where the silico-clastic rocks of the Roraima Group widely outcrop (Reid, 1974). This arenaceous group, of continental to peri-continental environment (Reid, 1974; Gosh, 1985), does not contain fossils. Its age should be comprised from 2.3-1.8 Ga of the granitic basement and the 1.4$1.8 \mathrm{Ga}$ of the basaltic dikes and sills that cross the Roraima Group (Briceño et al., 1990).

A slight metamorphism, with quartz-pirophillyte paragenesis in the pelitic beds, is the result of the load of a now eroded cover of almost $3 \mathrm{~km}$ thickness (Urbani et al., 1977).

\section{Stratigraphy}

In the Auyán-tepui region, rocks of the Roraima Group prevalently outcrop. The main relieves, from the top of the plateau to the foot of the scarps, are made up by ortoquartzites to protoquartzites and subarkoses with subordinate beds of middle-fine grained lithic wackes. This rocks belong to the stratigraphic unit named Matauí Formation by Reid (1974). Along the slopes which connect the foot of the walls with the 
pediment of the Caroní valley, protoquartzites, arkoses and wackes, with beds of cherts, lutites and siltites, of the Uaimapué Formation (Reid, 1974) outcrop. The two formations have a sequence of facies shoving the passage from a fluvial-deltaic environment to a proximal coastal one, with NW to SW transport directions. In the low-lands the Kukenán Formation, made up prevantely by siltites and shales, outcrops. A wide sills of diabase cover the Matauì Formation for almost $100 \mathrm{~km}^{2}$ (Fig. 1) in the central part of Auyàntepui (Briceño, 1985).

On the plateau and along the external walls, an alteration crust hides part of the fabric features of the rocks. The best outcroppings are in the caves, where we find clean erosional surfaces; in the SAN, the good conditions of outcropping have allowed to draw the schematic lithological section of Fig. 2.

Around the area where SAN opens, big residual blocks of a fine ortoquartzite, of red-wine color and with concoid fracture, are preserved on the litho-structural surface of $1670 \mathrm{~m}$. Just below this capping hard rock we find medium-fine quartzitic arenite, either white or ocraceous in color, with cross-laminated beds of $10-50 \mathrm{~cm}$ in thickness. Going down, the grain size increases, and about $120 \mathrm{~m}$ below the entrance there are beds of coarse arenite and rudite, with pebbles of white and ialine quartz, with scour contacts and erosion pockets. Around the depth of $170 \mathrm{~m}$, we observed again beds of mediumfine arenite with bedding surfaces modelled with ripples.

The arenite passes gradually to a coarse orthoquarzite with beds of 1-2 m of thickness. The contacts surfaces of beds are locally erosive and show pockets filled with pebbles of white or pinkish quartz. $290 \mathrm{~m}$ below the surface, the coarse ortoquartzite lays with an erosive contact on ocraceous-pinkish protoquartzite and arkose, finely laminated, with crossbedding and red beds; the quartz pebbles disappear. This contact probably separates two sedimentary phases.

This stratigraphic section of almost $300 \mathrm{~m}$ of thickness, contains two main negative sequences which show the passage from coarse deposits of a high energy depositional environment to fine cross-bedded sandstones, of lower energy, with tractive structures.

Going down we found a coarse arenite with local lenses of rudite, while in the deepest part of the cave we found again the medium-fine arenite.

\section{TECTONIC SETTING}

The main tectonic elements are some sets of fractures, mainly vertical, which cut the plateau in prisms of quadrangular shape. Folding structures are absent, except at a very large scale. The bedding is normally horizontal, locally slightly inclined. Faults have not been observed, at any scale.

In the areas investigated the main sets of fractures are oriented about NNW-SSE and NNE-SSW. Near the rims of the platform there are deep open fractures oriented WNW-ESE.

The main directions of fractures are well emphasized by the plan of the SAN (Fig. 3). A statistic analysis show that the directions of maximum development of the cave are prevalently around $160^{\circ}$, and around $50^{\circ}$. Along the first direction we found the largest simas, while a small difference in the orientation of the fractures has been observed in the surface in respect with the deepest part of the cave. The meso-structural survey of joints on surface didn't reveal the existence of direction around $50^{\circ}$.

(next page) Fig. 2 - Profile of the Sima Auyàn-tepui Noroeste compared with the schematic lithostrathigraphic section. Note the influence function of lithology on the vertical development of cave. 1) Beds of lutite and chert; 2)Cross bedded mediumfine arenite; 3) Coarse arenite and rudite, prevalently massive; 4) Ripples; 5) Scour contacs; 6) Main erosion surface. 


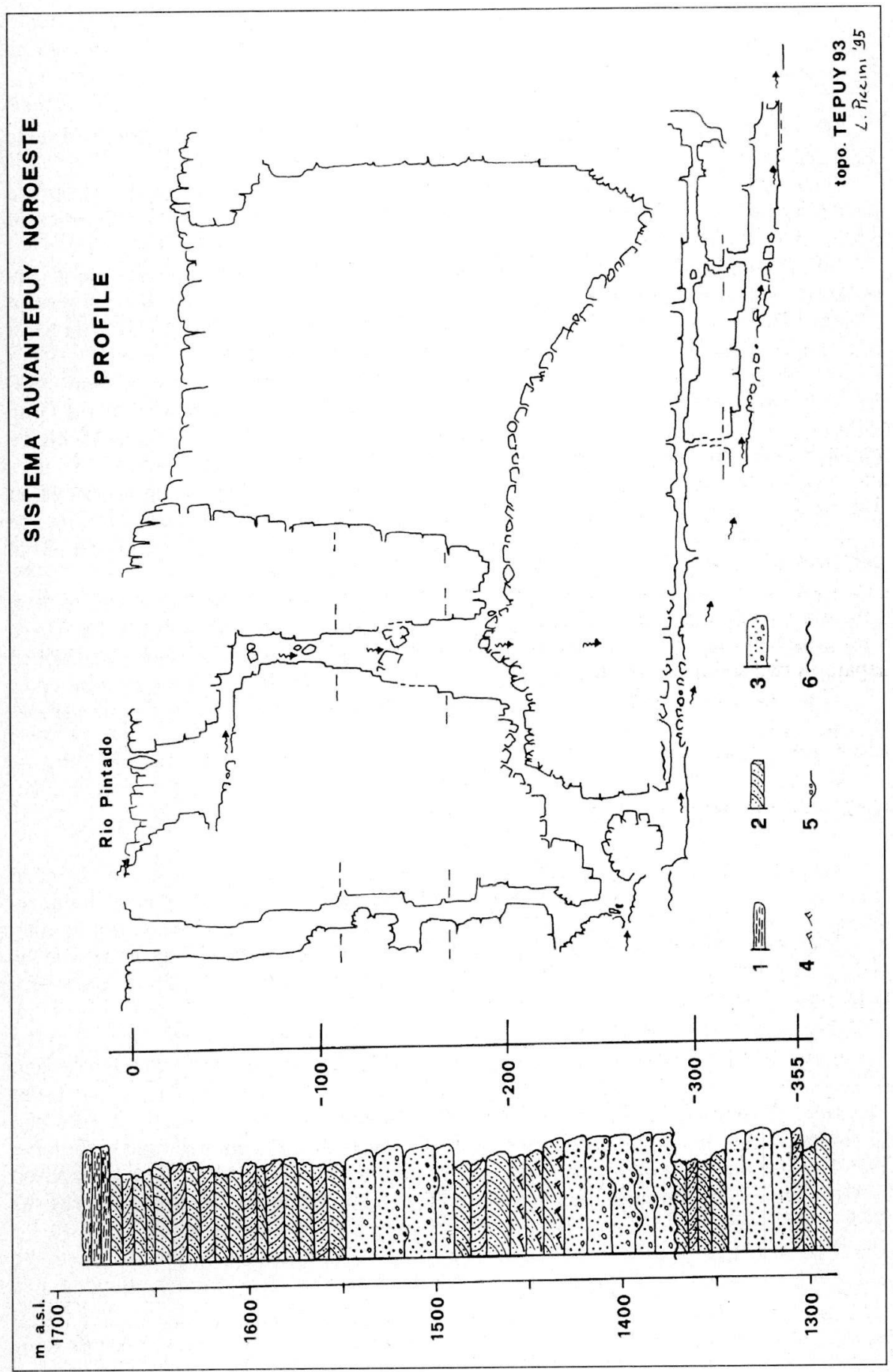




\section{GEOMORPHOLOGY}

\section{General morphology}

The Auyán-tepui is a wide tabular mountain, with an upper sommital plane and some intermediate planation surfaces of differential erosion at lower altitudes.

The summit surface of the plateau has a gradine-shape profile, descending from the $2800 \mathrm{~m}$ of the eastern side towards the western side, the lower, which has an elevation of about $1500-1600 \mathrm{~m}$, the average altitude of the plateau being about $2000 \mathrm{~m}$ a.s.l.

In the central part of the plateau, the deep valley of Rio Churún receives the waters of the plateau from several waterfalls (Fig. 4). The highest waterfall is the impressive Angels Fall, almost $1000 \mathrm{~m}$ high, but many other waterfalls are higher than $500 \mathrm{~m}$. Most of the superficial drainage is centripetal, towards the Churún Valley.

The tepuy rises from a planation surface situated at an average altitude of about 1000 $m$ a.s.l.. This surface represents the main surface that forms the lowlands of the Gran Sabana. No sure elements exist concerning its age, but it seems to be correlated with the Gondwana Surface of Brazil and Africa of Jurassic or older age (King, 1956)

The upper plane of the plateau is above the altitude of $2500 \mathrm{~m}$ and is part of an planation surface, named Auyán-tepui Surface by Briceño \& Schubert (1990). The age of this ancient peneplain is not known as well, because of the lack of any temporal element to date it; the authors hypotize a Triassic-Jurassic age.

Between these two main planation surfaces, the Auyán-tepui presents several generations of intermediate horizontal platforms which draw a gradinate profile. These non-sommital surfaces are the result of different cycles of selective erosion, conditioned by the presence of lithological changes. Normally the widest platforms are formed in correspondence of bed of fine hard rocks, more resistent to erosion, capping more erodible beds.

\section{Superficial landforms}

The peculiar landforms on the summit surface of the tepuy are the result of chemical weathering processes. This origin, together with the existence of a subterranean drainage, leads us to define the landscape of the tepuy a karstic landscape, as already proposed by Urbani $(1986 ; 1990)$. The importance of the chemical weathering of quartzarenites is well emphasized by landforms typical of calcareous karst landscapes: karren, kamenitza, stone-forests, etc.

The chemical solution attacks mainly the silica cement of arenites, leading to the "arenisation" of the rock, which can be thus carried away by washing waters (Urbani, 1986). This process acts mainly along the joints where the low velocity of the water corresponds to a longer time of reaction between water and rock. On the surface and along the walls of canyons and simas the runoff waters have not enough time to dissolve the silica cement of quartzitic arenites. On the contrary, on the surfaces of rocks exposed to the meteoric weathering, the alternation of wet and dry periods moves upwards the waters for capillarity to deposit a hard crust of silica cement and iron oxids .

The development of a karst-type landscape has been possible because the environmental conditions have limited the effects of mechanic weathering, allowing, in a 


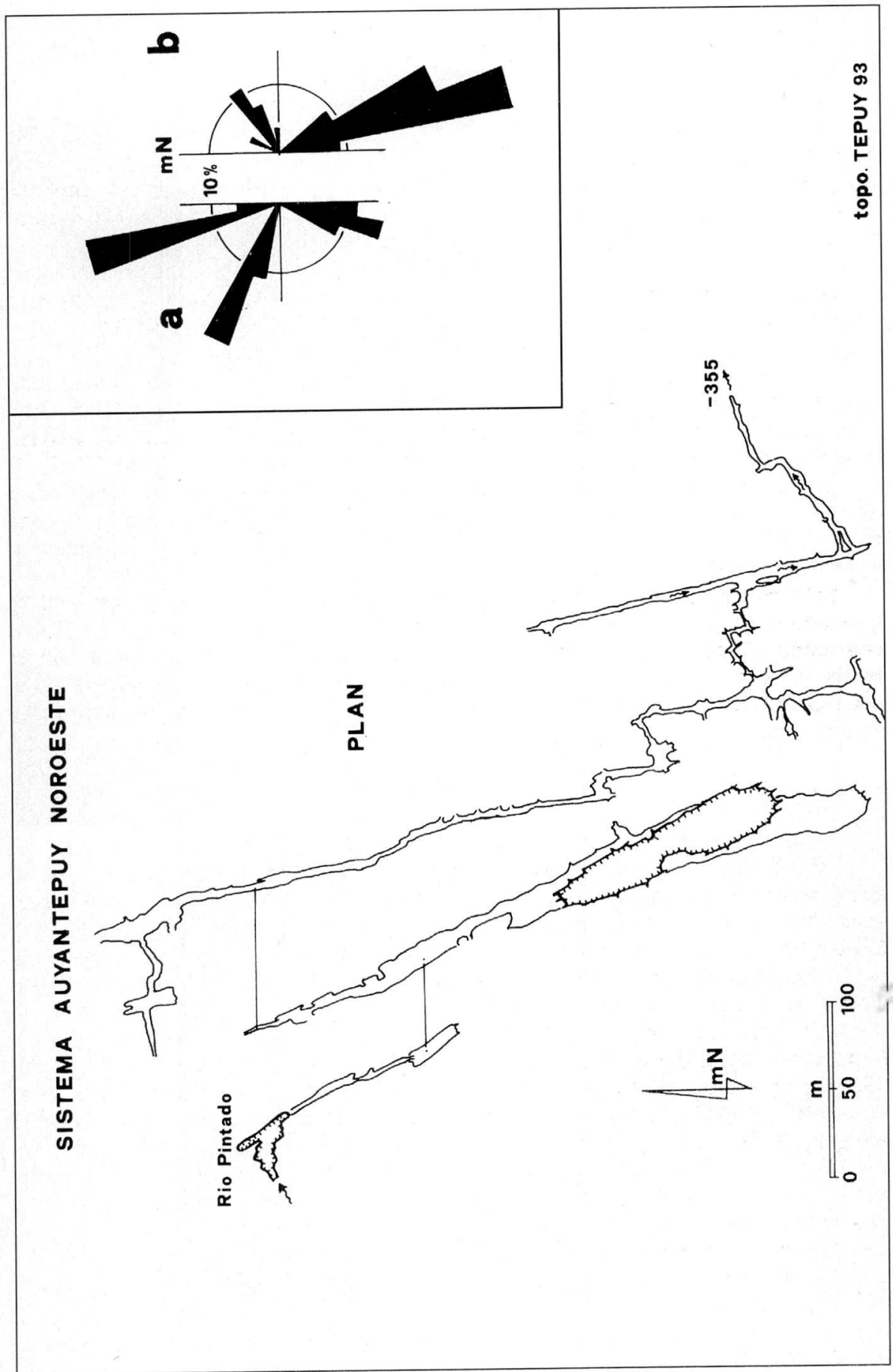


very long time, the development of solution forms. These plateaus are in fact subject to weathering from the end of Cretacic at least, in a state of almost absolute tectonic quiescence and with a very low morphologic gradient.

Fig. 4 - A spectacular twin waterfall. The height is approximatively $400 \mathrm{~m}$ (photo $\mathrm{P}$. Pezzolato - Tepuy '93).
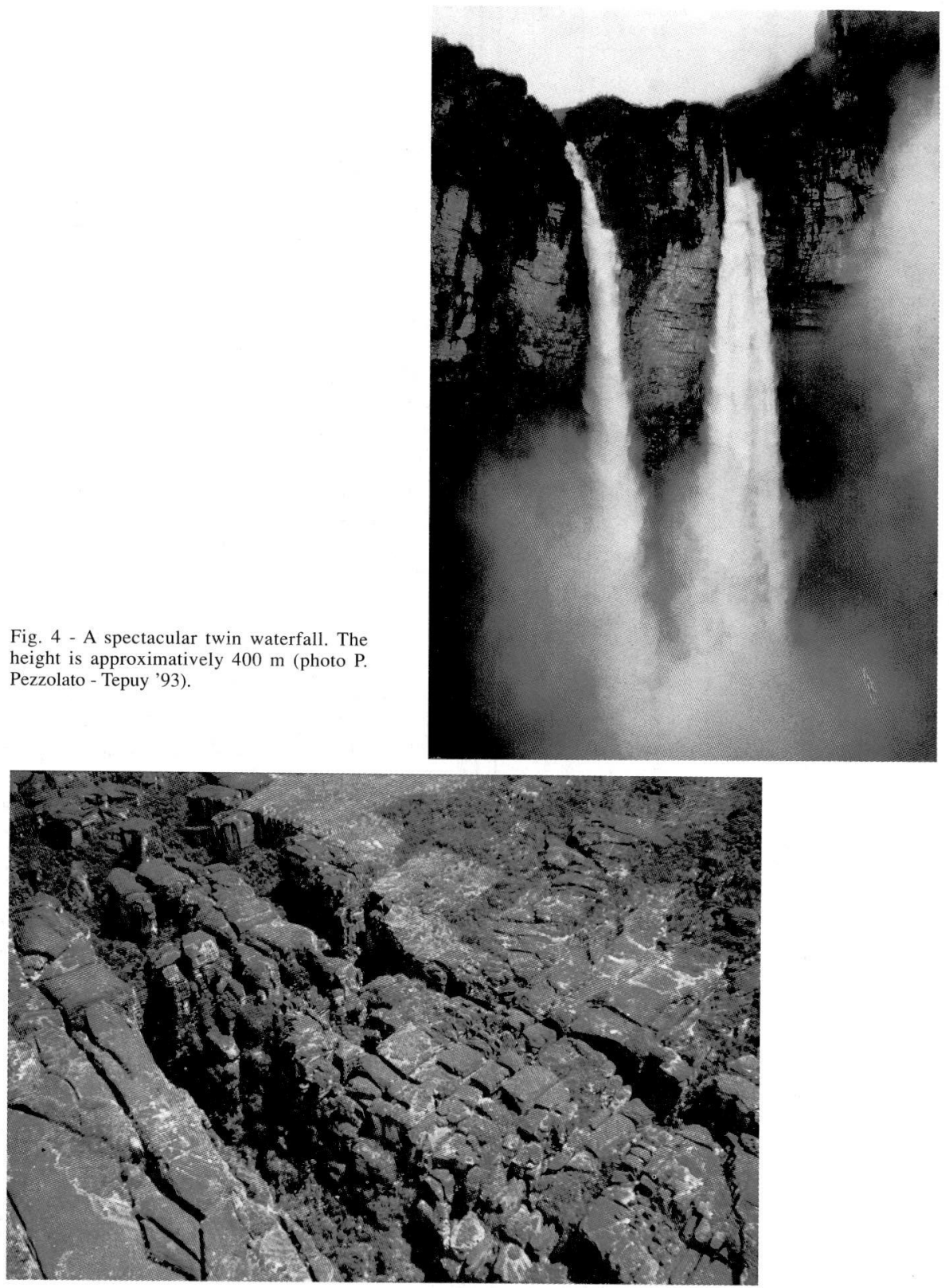

Fig. 5 - A system of fissures developed along joints on the summit surface of Auyàn-tepui (photo L. Piccini - Tepuy '93). 
The importance of the time factor is suggested by the low solubility of $\mathrm{SiO}_{2}$. A sampling of superficial waters gave concentrations of $\mathrm{SiO}_{2}$ of $0.2-0.4 \mathrm{mg} / \mathrm{l}$, while percolating waters collected in the caves have concentrations ranging from 1 to $2 \mathrm{mg} / \mathrm{l}$.

Mechanical-erosive processes are also active, but only along the streams, mainly near the border of the plateau, and inside the active caves.
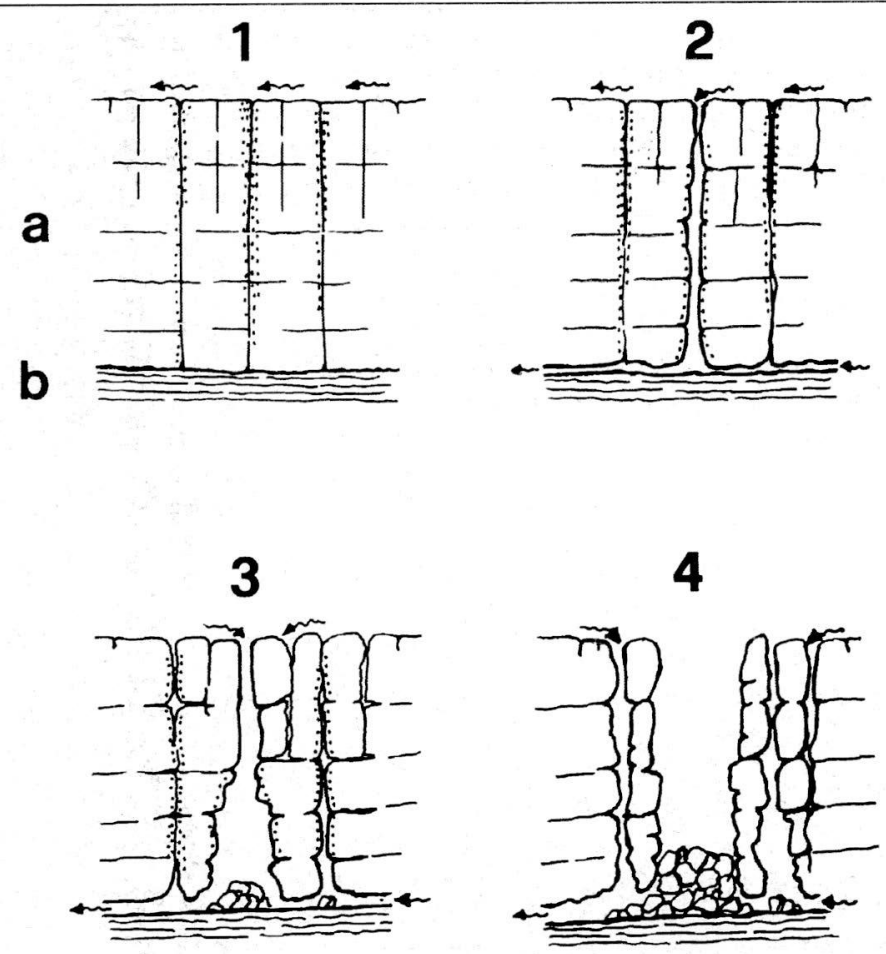

Fig. 6 - Evolution of a sima: a) coarse arenite; b) medium-fine arenite. See the text for explanations.

On the surface of the plateau we mainly saw landforms due to selective erosion. The small scale landforms undergo a lithologic control, while the large scale ones are controlled by tectonic features. These landforms can be divided between positive or negative ones.

Rock towers and pinnacles are the most abundant positive landforms on the plateau. We found two different kinds of rock towers. Near the border of the plateau there are towers with quadrangular shape with a height varying from some ten to some hundred of meters. They are prevalently due to solution-erosion processes along fractures opened by scarp-release stresses.

Far from the rim of the plateau, the towers have smaller dimensions and are abundant mainly near the border of the secondary scarps which bound ther intermediate platforms. They often represent erosional "witness" normally capped by a hard fine ortquartzite.

On the inner side of the plateau we found stone forests of rock pinnacles, some meters high. Their origin is due to solution processes which act along joints. 
In its initial stage the erosion along joints gives origin to open fissures, from a few decimetres to several meters wide and from a few meters to several tens of meters deep. They often form a regular network along two or more joint sets (Fig. 5).

The large simas, the deepest of the negative forms, have a different origin; they are formed by the collapse of subterranean cavities.

\section{The simas}

The more impressive morphologic feature on the summit plane of tepuy are the simas: big shafts elonged in the direction of the fractures. Their size is sometimes very huge. The Sima Aonda, for example, is $360 \mathrm{~m}$ deep, $500 \mathrm{~m}$ long and about $100 \mathrm{~m}$ wide. Often the simas are deeper than $100 \mathrm{~m}$, and they are more abundant near the border of the plateau.

Figure 6 shows a simplified evolutionary scheme of a sima. A fracture is enlarged by solution processes until it reaches an important lithologic change, frequently where coarse arenites and rudites pass to fine and more erodible arenites. In correspondence of this horizon, and in a very long time, interstratal conduits forms a drainage network with horizontal water flow. The presence of subterranean drainage allows the piping of the "arenisated" rock along the fractures.

Along the main axis of subterranean drainage network, the cave enlarges laterally until its size is such to cause the collapse of overstanding rock. The collapsed blocks can be successively mechanically eroded by deep waters flowing through the cave network.

The cavity so formed enlarges progressively towards the surface; when it reaches the surface a sima is formed. The largest simas are probably due to the coalescence of different simas.

The initial stages of the formation of a sima can be found far from the border of the plateau while the evolutive stages can be found closer to the rims of the plateau.

During our descent in the chasms of the Auyàn-tepui we had the possibility to observe the different evolutive stages in the formation of a simas. The firs part of the "Sumidero del Rio Pintado" (Fig. 2), the active sinkhole of the SAN, represent a good example of the stage of youth. The "Sima Aonda 3" represents a middle stage; the width of this chasm is 3-4 meters until the depth of $50 \mathrm{~m}$, then the fracture is less than one meter wide. Suddenly, at the depth of $200 \mathrm{~m}$, a large cavity, about $15 \mathrm{~m}$ wide, opens. At the bottom of the chasm, $300 \mathrm{~m}$ deep, a chaos of big rock blocks doesn't allow to proceed.

The great chasm of "Sima Aonda" is a typical example of the final stage. With time this sima will open towards the wall of the plateau giving origin to a pseudo-canyon with vertical to overhanging walls.

The simas are landforms of the initial stage of the long process that lead to the formation of an erosion plane (Fig. 7). This process can be summarized as follows:

In the perimetral areas of the plateau, narrow and deep shafts form along the fracture due to tensional release. The shafts extend until they reach an important lithologic change where an embrional drainage network develops.

The shafts widen and become capture points of superficial waters, while the subterranean network is subject to enlargement by erosion. The simas so formed extend

(next page) Fig. 7 - Ideal profile across the rim of a tepuy, shoving the different stages of development of an intermendiate plane (from left to right): M) Matauí Formation; U) Uaimapué Formation; a) fine grained beds (lutite and chert); b) fine to coarse arenite; c) quartzitic-feldspatic arenite with interbedded siltites.

1) Residual blocks; 2) Fissures; 3) Simas; 4) Rock towers; 5) Chaos of blocks; 6) Active sinkhole; 7) Active resurgence. 


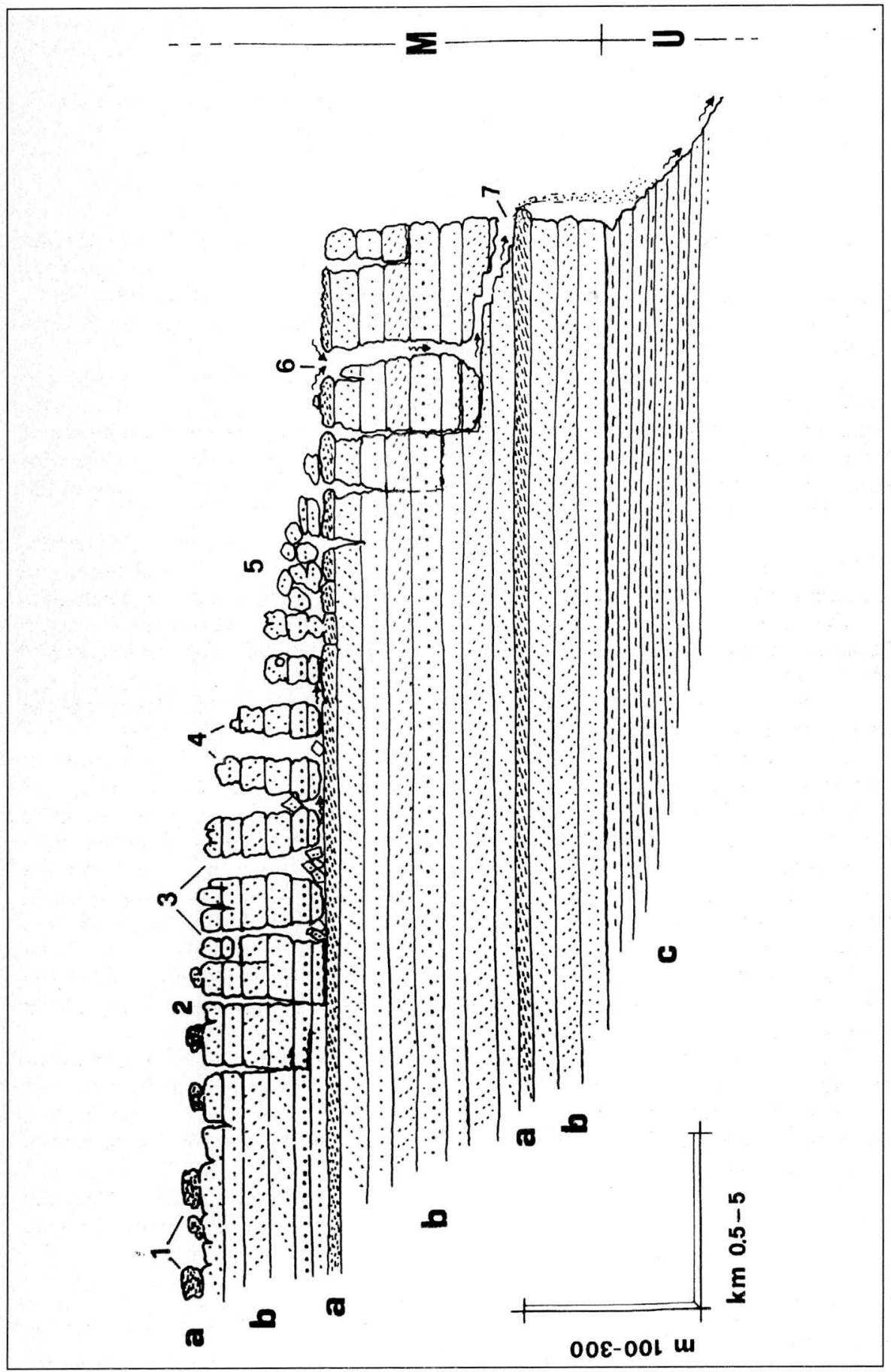


Fig. 8 - Temporary active gallery of the horizontal network (Sima Auyàn-tepui Noroeste, $-280 \mathrm{~m}$ ) (photo P. Pezzolato - Tepuy '93).

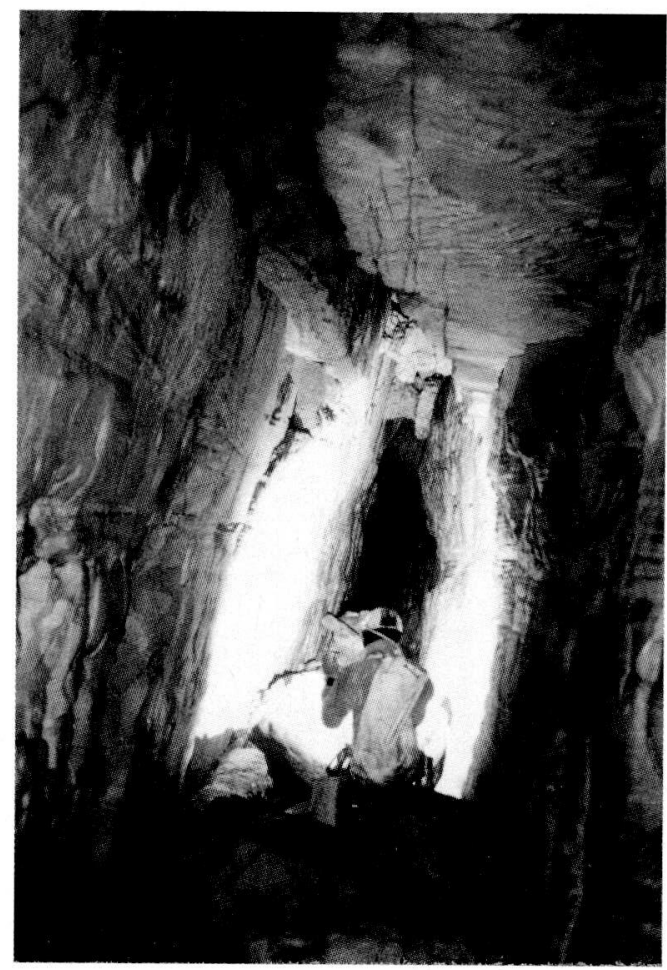

in the direction of the main fracture, joining together in a quadrangular-shape systems of pseudo-canyons which are opened towards the external cliff of the plateau; typically these deep chasms have great chaos of blocks at their bottom.

The enlargement of fissures, simas and canyons leads to the formation of large quadrangular towers. These towers are eroded at the base until they collapse, giving origin to impressive chaos of giant rock blocks. These blocks are progressively eroded, while under them the water rills towards the rims of the plateau over a horizon of hard rock where joints already begin to be enlarged by solutional processes.

The height of the walls which bound the secondary platforms depends on the vertical variations of the lithologic features of the sedimentary succession. Normally the height of the scarps is from 50 to $200 \mathrm{~m}$.

This long process of morphological modelling causes the progressive retrograding of the scarps, which bound different secondary plane in the inner side of the plateau, with a velocity greater than that of the perimetral scarps of the massif.

\section{Morphology of caves}

The caves are originated from fractures acting like points of concentrated infiltration. They are the morphologic environment on the tepuys most subject to 
mechanical erosion. In other words the energy of rilling waters is generally greater in the subterranean drainage systems than in the superficial ones. In fact, if the initial stage of the formation of caves is mainly due to solutional processes along fractures and joints, their enlargement is mainly due to erosion and subsequent collapse.

The morphology of underground passages is simpler than in the carbonatic rock cave systems; their shape is often controlled by the bedding planes and by the joints, as we can see particularly in collapse chambers but also in erosion galleries (Fig. 8).

All the caves explored show a pattern strongly controlled by the joint sets. This is well emphasized by the planimetric view of the caves; the plan of SAN, for example, shows a distinct net structure along the main sets of fractures. The SAN is the most complex underground system presently known to exist in siliceous rocks. In this system most of the morphologic features typical of underground systems in siliceous rock can be found.

The main entrance is an active sinkhole. The subterranean canyon which takes origin from it is from 2 to $4 \mathrm{~m}$ wide and from 10 to $30 \mathrm{~m}$ tall. Lateral widening and braided conduits are developed along the bedding plane. The canyon reaches a large chamber of rectangular shape of collapse origin through a shaft about $120 \mathrm{~m}$ deep. The floor of the chamber is covered by a chaos of rock blocks. Below these blocks the fracture, along which the upper part of the cave is developed, can be found again. At the bottom of this fracture, less than one meter wide, a subterranean stream flows along a canyon, at the depth of almost $300 \mathrm{~m}$, which follows an important lithologic contact. Along this contact little conduits braid with the main one.

The most interesting forms can be seen in the network of inactive galleries, which branch off from the active canyon. These galleries have a subcircular cross-section and probably developed in phreatic conditions. Their ceiling is a rounded erosive surface with ceiling pockets. Probably these conduits formed during high meteoric flows. In such conditions the deeper parts of the subterranean systems are probably flooded with water.

\section{CONCLUSIONS}

The Auyán-tepui is one of the best studied quartzitic massif in the world, from a speleological point of view. Many of the several caves explored have a morphogenetic complexity that involve the action of different geomorphical agents during a very long time and under particular environmental conditions.

In the initial stage of caves development, the karstic process of solution of silica cement along joints has a very important role. This process acts also in depth allowing the formation of networks of horizontal galleries of phreatic origin.

The karst process acts mainly in the young stages of the formation of caves, while in the mature-senile stages the evolution of caves is mainly due to erosion and collapse, giving origin to the big shafts named simas.

The profile of cave systems and the underground drainage of runoff waters is controlled by vertical lithological variations. Currently the horizontal drainage networks are developed in correspondence of beds of medium-fine arenites, while the shafts normally cross the sequences of coarse arenites.

\section{AKNOWLEDGEMENTS}

I wish to thank Marco Mecchia and Elisabetta Preziosi for the collaboration in the field survey and the useful discussions, and Professor Frando Urbani (Sociedad 
Venezolana de Espeleologia) for critical reading of the manuscript and the support which was instrumental for the success of the expedition "Tepuy '93". Thanks also to all the Italian and Venezuelan friends of "Tepuy' 93 ".

\section{REFERENCES}

BERNABEI T., MECCHIA M., PEZZOLATO P., PICCINI L. \& PREZIOSI E. 1993. Tepuy '93; ancora Venezuela. Speleologia, Soc. Spel. Ital., 29: 8-23.

BRICEÑO H. O. 1985. Mapa fotogeológico de la cuenca media del Rio Caroní, Edo. Bolívar - Venezuela. VI ${ }^{\circ}$ Congr. Geol. Venezolano, Soc. Venez. de Geol., 8: 5628-5653.

BRICEÑO H. \& SCHUBERT C. 1990. Geomorphology of the Gran Sabana, Guayana Shield, Southeastern Venezuela. Geomorphology, 3: 125-141.

BRICEÑO H., SCHUBERT C. \& PAOLINI J. 1990. Table-mountain geology and superficial geochemistry: Chimantà Massif, Venezuelan Guayana Shield. Journ. of South Am. Earth Sc., 3: 179-194.

C.G.E.B. 1994. Tepuy '93. Progressione 30, Commiss. Grotte E. Boegan, Trieste, 17:2- 120.

GALÁN C. 1986. Informe general del expedictión SVE efectuada a Auyàn-tepui Norte y Aonda, 25 de Enero a 2 de Febrero de 1986. Bol. Soc. Venez. Espel., 22: 81-84.

GALÁN C. 1988. Cavernas y formas de superficie en rocas siliceas precámbricas del Grupo Roraima, Guayana, Venezuela. Bol. Soc. Venez de Espel., 23: 1-12.

GALÁN C. \& LAGARDE J. 1988. Morphologie et evolution des cavernes et formes superficielles dans les quartzites du Roraima (Venezuela). Karstologia, 11-12: 49-59.

GONZALEZ DE JUANA C., PICARD X. \& ITURRALDE J. M. 1980. Geología de Venezuela y de sus cuencas petrolífera. Edic. Foninvés, Caracas: 1-1031.

GOSH S. 1985. Geology of the Roraima Group and its implication. Bol. Geol., Pub. Esp., 10: 33-50.

GORI S., INGLESE M., TOGNINI P., TREZZI G. \& RIGAMONTI I. 1993. Auyàn-tepui, speleologia tropicale nelle quarziti. Speleologia, Soc. Spel. Ital., 28: 23-33.

KING L. C. 1956. A geomorphological comparison between eastern Brazil and Africa (Central and Southern). Q. J. Geol. Soc. London, 112: 445-474.

REID A. R. 1974. Stratigraphy of the type area of the Roraima Group, Venezuela. Bol. Geol., Pub. Esp, 6: $343-$ 353.

URBANI F. 1986. Notas sobre el origin de las cavidades en rocas cuarcíferas precámbricas del Grupo Roraima, Venezuela. Interciencia, 11: 298-300.

URBANI F. 1990. Algunos comentarios sobre terminología kárstica aplicada a rocas siliceas. Bol. Soc. Ven. Esp., 24: 5-6.

URBANI F., S. TALUKDAR S., SZCERBAN E. \& COLVÉE P. 1977. Metamorfismo de las rocas del Grupo Roraima, Edo. Bolívar y Territorio Federal Amazonas. Mem. V Congr. Geol. Venez., Caracas: 623638. 